\title{
Surface integrity of hardened bearing steel after milling
}

Assoc Prof. Jan Jersák, MSc., Ph.D. ${ }^{1}$, Prof. Ing. Nikolaj Ganev, Ph.D. ${ }^{2,}{ }^{3}$, Jaroslav Kovalčík, MSc. ${ }^{4}$, Štěpánka Dvořáčková MSc. et MSc., Ph.D. ${ }^{5}$, Jiři Karásek, MSc. ${ }^{6}$, Adam Hotař, MSc., Ph.D. ${ }^{7}$

$1,3,4,5,6$ Department of Manufacturing Technology and Assembly, Faculty of Mechanical Engineering, Technical University of Liberec,

${ }^{2}$ Department of Solid State Engineering, Faculty of Nuclear Sciences and Physical Engineering, Czech Technical University in Prague,

${ }^{7}$ Department of Material Science, Faculty of Mechanical Engineering, Technical University of Liberec.

Demands on a surface layer quality of machined components are still increasing with increasing of machining productivity. Changes of mechanical properties in the thin surface layer of a workpiece occur due to thermal and deformation effects of the cutting tool during machining. The aim of the present paper is a study of the surface layer of samples from hardened steel (14th grade of steel), which were milled using machines produced by TOS Varnsdorf a.s. The samples were milled with different tools from five manufacturers. Parameters of surface integrity, which comprehensively reflect the quality of surface layer after milling, were evaluated after the machining.

Keywords: metal cutting, milling of hardened steel, surface integrity, measurement

\section{References}

[1] NECKÁŘ, F., KVASNIČKA, I. Vybrané statě z úběru materiálu. Faculty of Mechanical Engineering, Czech Technical University in Prague, 1991. ISBN 80-01-00696-4 (in Czech).

[2] JERSÁK, J., aj. Vliv dokončovacího obráběni na kvalitu povrchové vrstvy obrobku. Manufacturing Engineering Výrobné inžinierstvo. Volume 6, 2008, No. 2. p. 17 - 20. ISSN 1335-7972 (in Czech).

[3] MACHEK, V., SODOMKA, J. Nauka o materiálu - kovy a kovové materiály, 2. part. Faculty of Transportation Science, Czech Technical University in Prague, 2002. ISBN 80-01-02568-3 (in czech).

[4] JERSÁK, J., aj. Lišty kalené. [Research report, 1. part - presentation]. Liberec. Technical University of Liberec, 2009. p. 31 (in Czech).

[5] NOVÁ, I. Materiály a strojírenská technologie. VŠST Liberec, 1990. ISBN 80-7083-033-6 (in Czech).

[6] MÁDL, J. Integrita povrchu po obrábění. Manufacturing Engineering - Výrobné inžinierstvo. Volume 6, 2008 , No. 2. p. 17 - 20. ISSN 1335-7972 (in Czech).

[7] MÁDL, J., VILČEK, I.,RÁZEK, V., aj. Tvrdé a přesné frézování. Strojírenská technologie. Volume XIII, 2008 , No. 4. ISSN 1211-4162 (in Czech).

[8] MÁDL, J., VILČEK, I., RÁZEK, V., aj. Vlastnosti povrchu po tvrdém obrábění. Strojírenská technologie. Volume XIII, 2008, No 3. ISSN 1211-4162 (in Czech).

[9] GANEV, N., aj. Rtg. difrakční studium povrchové vrstvy kalených vodících lišt opracované frézováním. [part of Research report]. Czech Technical University in Prague, 2009. p. 19 (in Czech).

[10] KRAUS, I., GANEV, N. Technické aplikace difrakční analýzy. Czech Technical University in Prague, 2004. ISBN 80-01-03099-7 (in Czech).

Reviewers:

Prof. Jan Mádl, MSc., Ph.D.

Prof. František Holešovský, MSc., Ph.D. 